\title{
Influence of sowing times and plant populations on the agronomic performance of maize hybrids
}

\section{Influência de épocas de semeadura e populações de plantas no desempenho agronômico de híbridos de milho}

\author{
Leonardo Fernandes LEITE'; Luan Marlon RIBEIRO²; Adriano dos SANTOS ${ }^{3}$; Valdecir Batista ALVES ${ }^{4}$; \\ Priscila Akemi MAKINO5; Gessí CECCON ${ }^{6}$ \\ ${ }^{1}$ Mestre em Produção Vegetal, Universidade Federal da Grande Dourados/UFGD, leofernandes_16@hotmail.com \\ 2 Autor para correspondência, Doutorando em Produção Vegetal, Universidade Federal da Grande Dourados/UFGD, Rod. \\ Dourados - Itahum, km 12, CEP 79805-095, Cidade Universitária, Dourados, MS, luanmarlon@hotmail.com \\ ${ }^{3}$ Doutorando em Genética e Melhoramento de Plantas, Universidade Estadual do Norte Fluminense Darcy Ribeiro/UENF, \\ adriano.agro84@yahoo.com.br \\ ${ }^{4}$ Doutor em Produção Vegetal, AGRAER - Agência de desenvolvimento e extensão rural, valdecirbalves@hotmail.com \\ ${ }^{5}$ Doutoranda em Produção Vegetal, Universidade Federal da Grande Dourados/UFGD, priscila_akemi17@hotmail.com \\ ${ }^{6}$ Doutor em Agronomia, Pesquisador-Embrapa Agropecuária Oeste, gessi.ceccon@embrapa.br
}

Recebido em: 08-01-2018; Aceito em: 15-02-2018

\begin{abstract}
The sowing time, along with increased plant density and the choice of the hybrid, are among the main factors to obtain higher grain yields in second-season maize. The objective was to evaluate the agronomic performance of maize hybrids grown in different plant populations and sowing times. The experimental design was in randomized blocks with subdivided plots and four replicates. The main plots consisted of four sowing times (Jan/20/2014, Feb/07/2014, Feb/28/2014, and Mar/14/2014), the subplots consisted of the hybrids (BRS 1010 and DKB 390 VT PRO2), and the sub-subplots consisted of the plant populations $(45,000 ; 55,000 ; 65,000$ and 75,000 plants ha-1). Regardless of plant population, the performance of hybrids BRS 1010 and DKB 390 VT PRO2 are similar regarding grain yield, plant height, and number of rows per ear. The development of maize was better in the sowings performed between Jan/20 and Feb/07, and very late sowings negatively affect yield. Among the hybrids studied, in a population ranging from 45,000 to 75,000 plants $^{-1}{ }^{-1}$ there is a reduction in ear diameter and hundred-grain weight, although without affecting yield.
\end{abstract}

Additional keywords: agronomic characteristics; grain yield; plant arrangement; Zea mays.

\section{Resumo}

A época de semeadura, o aumento da densidade de plantas e a escolha do híbrido estão entre os principais fatores para obtenção de maiores produtividades de grãos do milho de segunda safra. Objetivou-se avaliar o desempenho agronômico de híbridos de milho, cultivados em diferentes populações de plantas e épocas de semeadura. $O$ delineamento experimental foi o em blocos casualizados, com parcelas subsubdivididas, com quatro repetições. As parcelas principais foram compostas por quatro épocas de semeadura (20/jan/2014, 07/fev/2014, 28/fev/2014 e 14/mar/2014), as subparcelas, pelos híbridos (BRS 1010 e DKB 390 VT PRO2), e as subsubparcelas pelas populações de plantas $(45 ; 55 ; 65$ e 75 mil plantas ha-1). Independentemente da população de plantas, o desempenho dos híbridos BRS 1010 e DKB 390 VT PRO2 coincidem quanto à produtividade de grãos, à altura de plantas e ao número de fileira por espiga. $O$ desenvolvimento do milho foi melhor em semeaduras realizadas entre 20/jan e $07 / f e v$, e semeaduras muito tardias afetam negativamente a produtividade. Dentre os híbridos estudados, em população variando de 45 a 75 mil plantas ha ${ }^{-1}$, ocorre redução do diâmetro de espiga e massa de 100 grãos, porém sem afetar a produtividade.

Palavras-chave adicionais: arranjo de plantas; características agronômicas; rendimento de grãos; Zea mays.

\section{Introduction}

The sowing of maize in Brazil occurs traditionally in two times, namely the $1^{\text {st }}$ and $2^{\text {nd }}$ crop ("safrinha"). The latter used to be considered a supplementary sowing to the income of producer however, this denomination should no longer be used, due to the good yields obtained in this period (Cherubin et al., 2014). Moreover, second-season maize provides the agronomic benefits of crop rotation, such as the increase of straw over the soil, fundamental to the maintenance of the no-tillage system (Pereira et al., 2014).

The cultivation of second-season maize occurs from January, in succession to the soybean crop. In this period, the maize crop is subject to strong limitations of solar radiation, among other adverse environmental conditions such as low rainfall (Van 
Roekel \& Coulter, 2012). According to agricultural zoning (MAPA, 2018) in non-irrigated second-season maize crops, the availability of water for farming varies according to the rainfall distribution of each region and the sowing time, determining factors for greater increases in crop yield.

Given such conditions, it is necessary to define the best sowing time to minimize losses and damage to the crop. The sowing time has a great influence on plant development, but the population density is also another important factor for establishing the maize crop, since small changes in the plant density imply relatively large changes in grain yield due to its low capacity to emit fertile tillers, monoic floral organization, and short flowering period (Silva et al., 2010a).

According to Neto-Neto et al. (2013a), the efficiency of interception of solar radiation and its conversion and partition in photoassimilates depend on the hybrid used and the management practices, mainly regarding the plant arrangement used.

Crop yield increases when the planting density is increased until reaching an optimum density, determined by the cultivar and climatic conditions. The ideal population for maize varies from 30 to 90 thousand plants ha-1, depending on water availability, soil fertility, cultivar cycle, sowing time, and row spacing (Alves et al., 2013a).

Several modern hybrids have had their leaf architecture modified by genetic breeding; they have more erect leaves, increasing the efficiency of the use of natural resources, especially solar radiation, which is lower in August (Galvão et al., 2014a).

The use of high plant densities, associated with the use of hybrids with a compact architecture, may be an effective strategy to minimize the reduction in yield potential in second-season maize sowing (Alves et al., 2013b).

Thus, the objective of this work was to evaluate the agronomic performance of second-season maize hybrids as a function of the sowing time and population density.

\section{Material and methods}

The study was conducted in the experimental field of Embrapa Agropecuária Oeste, in the municipality of Dourados, Mato Grosso do Sul, at coordinates $22^{\circ} 13^{\prime} \mathrm{S}$, and $54^{\circ} 48^{\prime} \mathrm{W}$, at an altitude of $408 \mathrm{~m}$, in a tillage area. The soil was classified as dystroferric Red Latosol, with a very clayey texture (Santos et al., 2013). The soil chemical analysis at the $0-0.20 \mathrm{~m}$ layer showed the following results: $\mathrm{pH}\left(\mathrm{CaCl}_{2}\right)=6.2 ; \mathrm{V}=$ $79.3 \% ; \mathrm{OM}=37.9 \mathrm{~g} \mathrm{~kg}^{-1} ; \mathrm{P}=57.3 \mathrm{mg} \mathrm{dm}{ }^{-3} ; \mathrm{K}=1.0$ $\mathrm{cmol}_{\mathrm{c}}-\mathrm{dm}^{-3} ; \mathrm{Ca}=6.5 \mathrm{cmol}_{\mathrm{c}} \mathrm{dm}^{-3} ; \mathrm{Mg}=2.8 \mathrm{cmol}_{\mathrm{c}} \mathrm{dm}^{-3}$; and $\mathrm{Al}=2.7 \mathrm{cmol}_{\mathrm{c}} \mathrm{dm}^{-3}$.

The climate of Dourados, according to the Köppen classification, is type Am (tropical monsoon), with hot summers and dry winters, maximum temperatures observed in the months of December and January, and minimum temperatures between May and August, coinciding with excess rainfall in the springsummer period, and water deficit in the autumn-winter period (Santos \& Silva, 2012).

The rainfall and temperature data during the conduction of the experiment were obtained at the Embrapa Agropecuária Oeste Meteorological Station, located $300 \mathrm{~m}$ from the experimental area. The total rainfall in the experimental period was $688.6 \mathrm{~mm}$ (Figure 1).

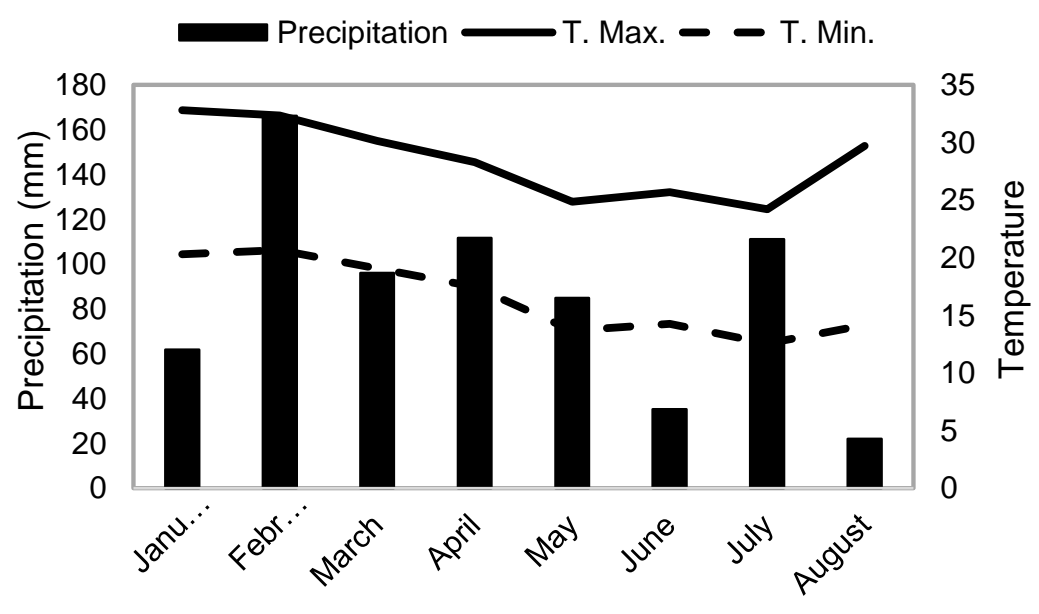

Figure 1 - Values of precipitation, maximum and minimum, temperatures recorded in the period from January to August during the conduction of the experiment. Source: Embrapa-CPAO (2014).

The experimental design was in randomized blocks in a split-plot arrangement with four replicates. The main plots consisted of four sowing times (Jan/20/2014, Feb/07/2014, Feb/28/2014, and Mar/14/2014), the subplots consisted of the hybrids (BRS 1010 and DKB 390 VT PRO2), and the sub-sub- plots consisted of the plant populations $(45,000$; 55,$000 ; 65,000$ and 75,000 plants ha ${ }^{-1}$ ). The experimental units consisted of eight 6-m long rows, spaced $0.50 \mathrm{~m}$ apart, in four replicates.

The experimental area was managed under a no-tillage system, in crop succession, where second- 
season maize is grown alone and intercropped with Brachiaria ruziziensis in the autumn-winter period, and with soybean in the summer. The experiment was carried out in the agricultural year of 2013/14, using the maize hybrids BRS 1010 and DKB 390 VT PRO2.

BRS 1010 is a simple hybrid that presents a wide adaptation in the Southeast and Center-West regions, in addition to an early cycle, good resistance to plant lodging and breaking, with upright leaf architecture and an orange semi-hard grain (Ferreira, 2012). DKB 390 VT PRO2 is a simple, early-cycle hybrid that presents yellow-orangish semi-hard grain, with wide adaptation in the Southeast region, and good resistance to plant lodging and breaking as well (Carvalho et al., 2011).

The seeds were treated with thiodicarb insecticide at a dose of $20 \mathrm{~mL} \mathrm{~kg}^{-1}$ seed, and sown by the Semeato $\AA$ seeder-fertilizer set, model SHP 248, equipped with a front cutting disc, a furrowing shank for fertilizer distribution in the quantity of $235 \mathrm{~kg} \mathrm{ha}^{-1}$ of the formula $10-25-15$ of $\mathrm{N}, \mathrm{P}_{2} \mathrm{O}_{5}$ and $\mathrm{K}_{2} \mathrm{O}$, respectively, and double disk for seed positioning. Plant thinning was performed ten days after emergence, which occurred 7 days after sowing.

Weed control was performed by desiccating the pre-planting area at a dose of $1.44 \mathrm{~L} \mathrm{ha}^{-1}$ of glyphosate acid equivalent. Post-emergence herbicide applications were performed using atrazine at the dose of $1.5 \mathrm{~L} \mathrm{ha}^{-1}$. Pests were controlled with the application of Thiamethoxam + Lambda-Cyhalothrin at the dose of $200 \mathrm{~mL} \mathrm{ha}^{-1}$, at 20 days after maize emergence.

At the tasseling stage (VT), when $50 \%$ of the plants presented receptive stigma, the total chlorophyll index of 5 plants in each experimental unit was measured using a FALKER ${ }^{\circledR}$ chlorophyll meter, model CFL 1030. The readings were done as recommended by Neto-Neto et al. (2013b), being performed on the first leaf below the ear at points located in the middle third of the sampled leaf, and at $2 \mathrm{~cm}$ from one of the leaf margins; the readings were done in the morning.

The morphological evaluations (plant height $\mathrm{PH}$, ear height - $\mathrm{EH}$, and stem diameter - SD) of maize plants were carried out near the R2 stage, in 5 plants of each experimental unit. At the physiological maturation stage of maize - R6, plant counting and ear collection were performed in the two central rows of the subsubplot to analyze yield components.

The collected ears went through the procedures of counting, determination of length (EL), diameter (ED), weight (EW), number of rows per ear (NRE), and number of ears per plot (NEP). After wards, they were tracked, and the hundred-grain weight (HGW) was determined. After grain weighing, grain yield was determined, with moisture correction to $13 \%$. In the evaluations of EL, ED, and EW, 5 ears with no straw from each experimental unit were evaluated, and the mean was obtained.

The data were submitted to analysis of variance by the $F$ test $(P<0.05)$. When significant, the hybrids and sowing times were submitted to the Tukey test $(P<0.05)$, and the quantitative data (plant population) was submitted to regression analysis, in which the significance of the tested model was considered. All analyses were performed using the Sisvar software.

\section{Results and discussion}

The results of the analysis of variance revealed significant differences $(p<0.01)$ for all the characters, except for number of rows per ear and number of ears per plot. This result shows that sowing times influence the performance of the evaluated characters (Table 1 and 2).

Table 1 - Summary of variance analysis for plant height (PH; m), ear height (EH; m), stem diameter (SD; mm), number of rows per ear (NRE) and ear diameter (ED; $\mathrm{mm}$ ) of two corn hybrids in four plant populations and four sowing seasons.

\begin{tabular}{|c|c|c|c|c|c|c|}
\hline \multirow{2}{*}{ Causes of variation } & \multirow{2}{*}{ FD } & \multicolumn{5}{|c|}{ Mean square } \\
\hline & & $\mathrm{PH}$ & $\mathrm{EH}$ & SD & NRE & ED \\
\hline Blocks & 3 & 0.004 & 0.003 & 4.065 & 1.270 & 2.721 \\
\hline Sowing times (S) & 3 & $0.571^{* *}$ & $0.801^{* *}$ & $152.331^{* *}$ & $15.514^{\mathrm{ns}}$ & $19.714^{\star *}$ \\
\hline Error A & 9 & 0.005 & 0.007 & 1.087 & 0.880 & 1.068 \\
\hline Hybrid $(\mathrm{H})$ & 1 & $0.006^{\mathrm{ns}}$ & $0.000^{\mathrm{ns}}$ & $14.837^{\star}$ & $5.334^{*}$ & $15.249^{* *}$ \\
\hline $\mathrm{S} \times \mathrm{H}$ & 3 & $0.399^{* *}$ & $0.475^{* *}$ & $4.707^{\mathrm{ns}}$ & $71.753^{* *}$ & $209.073^{* *}$ \\
\hline Error B & 9 & 0.027 & 0.003 & 2.781 & 0.617 & 0.991 \\
\hline Plant Population (P) & 3 & $0.007^{\mathrm{ns}}$ & $0.012^{*}$ & $8.851^{* *}$ & $0.488^{\text {ns }}$ & $19.147^{* *}$ \\
\hline$S \times P$ & 9 & $0.004^{\mathrm{ns}}$ & $0.005^{\text {ns }}$ & $1.850^{\text {ns }}$ & $0.598^{\text {ns }}$ & $2.974^{\mathrm{ns}}$ \\
\hline $\mathrm{H} \times \mathrm{P}$ & 3 & $0.007^{\mathrm{ns}}$ & $0.004^{\mathrm{ns}}$ & $0.669^{\text {ns }}$ & $0.879^{\text {ns }}$ & $1.805^{\mathrm{ns}}$ \\
\hline $\mathrm{S} \times \mathrm{H} \times \mathrm{P}$ & 9 & $0.002^{\mathrm{ns}}$ & $0.003^{\text {ns }}$ & $2.353^{\text {ns }}$ & $0.461^{\text {ns }}$ & $2.075^{\mathrm{ns}}$ \\
\hline Error C & 75 & 0.004 & 0.004 & 1.886 & $0.534^{\mathrm{ns}}$ & 1.865 \\
\hline CV1 (\%) & 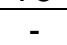 & 3.53 & 7.56 & 5.03 & 6.19 & 2.11 \\
\hline CV2 (\%) & - & 2.69 & 5.30 & 8.05 & 5.18 & 2.04 \\
\hline CV3 (\%) & - & 3.01 & 6.37 & 6.63 & 4.82 & 2.79 \\
\hline Mean & & 2.06 & 1.08 & 20.73 & 15.16 & 48.92 \\
\hline
\end{tabular}

${ }^{* \star},{ }^{*}$, ns: Significant at $1 \%$, significant at $5 \%$, and not significant by the $\mathrm{F}$ test, respectively; $\mathrm{CV}$ : variation coefficient. 
There is a significant effect of hybrids for stem diameter, number of rows per ear, ear diameter, ear length, grain yield, and total chlorophyll, indicating the existence of a difference between the hybrids evaluated, mainly in relation to yield components.

Table 2 - Summary of variance analysis for ear length (EL; cm), number of ear per plot (NEP), grain yield (Yield; $\mathrm{kg} \mathrm{ha}^{-1}$ ), hundred-grain weight (HGW; g) and total chlorophyll (ChlorT; clorophyll a + clorophyll b) of two corn hybrids in four populations of plants and four sowing times.

\begin{tabular}{|c|c|c|c|c|c|c|}
\hline \multirow{2}{*}{ Variation factors } & \multirow{2}{*}{ FD } & \multicolumn{5}{|c|}{ Mean square } \\
\hline & & EL & NEP & Yield & HGW & ChlorT \\
\hline Blocks & 3 & 0.678 & 16.913 & $1,451,737.499$ & 4.757 & 79.768 \\
\hline Sowing times (S) & 3 & $11.617^{\star *}$ & $21.246^{\mathrm{ns}}$ & $6,400,101.819^{* *}$ & $58.419^{* *}$ & $168.107^{\star \star}$ \\
\hline Error A & 9 & 0.881 & 9.239 & $537,251.874$ & 4.894 & 27.222 \\
\hline Hybrid $(\mathrm{H})$ & 1 & $16.337^{\star \star}$ & $9.753^{\text {ns }}$ & $2,325,205.690^{\star}$ & $3.128^{\text {ns }}$ & $508.606^{* *}$ \\
\hline $\mathrm{S} \times \mathrm{H}$ & 3 & $2.871^{* *}$ & $53.496^{\star *}$ & $13,228,834.567^{\star *}$ & $42.859^{* *}$ & $18.514^{\text {ns }}$ \\
\hline Error B & 9 & 0.139 & 6.109 & $146,296.755$ & 0.534 & 6.856 \\
\hline Plant Population (P) & 3 & $10.787^{\star *}$ & $452.753^{* *}$ & $448,910.634^{\mathrm{ns}}$ & $61.817^{\star *}$ & $186.582^{* *}$ \\
\hline$S \times P$ & 9 & $0.539^{\text {ns }}$ & $11.885^{\star}$ & $266,817.547^{\mathrm{ns}}$ & $1.654^{\text {ns }}$ & $13.835^{\text {ns }}$ \\
\hline $\mathrm{H} \times \mathrm{P}$ & 3 & $0.827^{\text {ns }}$ & $4.253^{\mathrm{ns}}$ & $1,192,616.07^{\mathrm{ns}}$ & $2.343^{\text {ns }}$ & $11.338^{\text {ns }}$ \\
\hline $\mathrm{S} \times \mathrm{H} \times \mathrm{P}$ & 9 & $1.279^{\star}$ & $12.552^{*}$ & $904,046.768^{\mathrm{ns}}$ & $2.945^{\text {ns }}$ & $5.444^{\mathrm{ns}}$ \\
\hline Error C & 75 & 0.518 & 5.657 & $508,527.873$ & 2.585 & 19.442 \\
\hline CV1 (\%) & - & 6.87 & 12.04 & 11.88 & 7.25 & 8.03 \\
\hline CV2 (\%) & - & 2.73 & 9.79 & 6.20 & 2.39 & 4.03 \\
\hline CV3 (\%) & - & 5.27 & 9.42 & 11.56 & 5.27 & 6.78 \\
\hline Mean & - & 13.67 & 25.25 & $6,171.12$ & 30.53 & 65.01 \\
\hline
\end{tabular}

${ }^{* *},{ }^{*}$, ns: Significant at $1 \%$, significant at $5 \%$, and not significant by the $\mathrm{F}$ test, respectively; CV: variation coefficient.

The significant effect for the interaction sowing times $x$ hybrids $(\mathrm{S} \times \mathrm{H})$ indicates, for such variables, that the average performances of the hybrids were not coincident in the different sowing times used. In this way, one must evaluate the unfolding of this interaction to identify the best sowing time for each hybrid.

For the source of variation "plant population" $(P)$, there was a significant effect for most of the characters, however, no effect was observed for grain yield, agreeing with the results of Resende et al. (2003), who stated that maize yield is not always affected by the plant population. The authors concluded that the best plant density to obtain higher maize grain yields depends on the agricultural year, and there may be no differences for yield at densities ranging from 55 to 90,000 plants ha-1 as a function of climatic conditions.

The interactions between plant population and the other factors were all not significant, except for EL and NEP in the triple interaction $(\mathrm{S} \times \mathrm{H} \times \mathrm{P})$. When the triple interaction effect is significant, one approach would be to perform two analyses of variance separately, one for each level of the third factor, and to use the residue of the original three-way analysis of variance, in order to better explain the effects of the interaction, since a simultaneous analysis of the three factors is not feasible.

The coefficients of variation presented, for the most part, values lower than 10 , indicating a good experimental precision. Both hybrids showed higher ear height in the first sowing time (January 20) compared to later sowings (Table 3). In this way, it can be inferred that later sowings lead to smaller plant size and, consequently, lower ear insertion height. This result may be related to the lower rainfall occurring during later sowings, resulting in lower plant development (Figure 1).

The reduction in plant and ear height, mainly for the hybrid BRS 1010 when sown lately, is in agreement with the results found by Silva et al. (2010b); the authors stated that, when comparing the different sowing times, the late ones present low mean values of plant height in relation to the cultivation in the normal season.

It is observed that the hybrids showed a certain alternation for plant and ear height according to each sowing times. This result corroborates the results obtained by Costa et al. (2017) when evaluating the performance of different maize cultivars and concluding that plant height was highly influenced both by the genetic constitution of the material and by climatic conditions, which provided the great variation observed in their studies.

Similarly, the highest values of ear diameter and number of rows per ear were also obtained at 
times where the highest development of plant and ear height was favored. Thus, the adaptation of the hybrids in each region depends mainly on the sowing time (Table 4).

Table 3 - Synthesis of the interaction sowing time $x$ hybrid referring to the characteristics of plant height and ear height.

\begin{tabular}{lccccc}
\hline \multirow{2}{*}{ Sowing time } & \multicolumn{2}{c}{ Plant height $(\mathrm{m})$} & & \multicolumn{2}{c}{ Ear height $(\mathrm{m})$} \\
\cline { 2 - 3 } \cline { 5 - 6 } & DKB 390 & BRS 1010 & & DKB 390 & BRS 1010 \\
\hline January 20 & $2.09 \mathrm{bB}$ & $2.33 \mathrm{aA}$ & & $1.17 \mathrm{aB}$ & $1.37 \mathrm{aA}$ \\
February 7 & $2.21 \mathrm{aA}$ & $2.03 \mathrm{bB}$ & & $1.23 \mathrm{aA}$ & $1.07 \mathrm{bB}$ \\
February 28 & $1.84 \mathrm{cB}$ & $2.00 \mathrm{bA}$ & & $0.83 \mathrm{cB}$ & $1.06 \mathrm{bA}$ \\
March 14 & $2.06 \mathrm{bA}$ & $1.88 \mathrm{cB}$ & & $1.07 \mathrm{bA}$ & $0.83 \mathrm{cB}$ \\
\hline
\end{tabular}

Means followed by the same lowercase letters in the column and upper case in the row do not differ statistically from each other by Tukey's test $(p>0.05)$.

Tabela 4 - Deployment of the interaction sowing time $\mathrm{x}$ hybrid referring to the characteristics ear diameter and number of rows per spike.

\begin{tabular}{lllllc}
\hline \multirow{2}{*}{ Sowing time } & \multicolumn{2}{c}{ Ear diameter $(\mathrm{mm})$} & & \multicolumn{2}{c}{ Number of rows per ear } \\
\cline { 2 - 3 } \cline { 5 - 6 } & DKB 390 & BRS 1010 & & DKB 390 & BRS 1010 \\
\hline January 20 & $46.60 \mathrm{cB}$ & $51.81 \mathrm{aA}$ & & $14.05 \mathrm{bB}$ & $16.92 \mathrm{aA}$ \\
February 7 & $50.82 \mathrm{aA}$ & $45.86 \mathrm{cB}$ & & $17.02 \mathrm{aA}$ & $13.97 \mathrm{bB}$ \\
February 28 & $47.47 \mathrm{cB}$ & $52.29 \mathrm{aA}$ & & $14.07 \mathrm{bB}$ & $17.02 \mathrm{aA}$ \\
March 14 & $49.35 \mathrm{bA}$ & $47.05 \mathrm{bB}$ & & $14.69 \mathrm{bA}$ & $13.55 \mathrm{bB}$ \\
\hline
\end{tabular}

Means followed by the same lowercase letters in the column and upper case in the row do not differ statistically from each other by Tukey's test $(p>0.05)$.

For ear length, the first sowing time was characterized as the most favorable for the development of this character in both hybrids. When comparing the hybrids within each sowing times, it was observed that the hybrid DKB 390 presented, in general, higher averages, not differing, however, from BRS 1010 at later sowings (Table 5).

Table 5 - Synthesis of the interaction of sowing time $x$ hybrid referring to the characteristics of ear length, grain yield and hundred-grain weight.

\begin{tabular}{llllll}
\hline \multirow{2}{*}{ Sowing time } & \multicolumn{2}{c}{ Ear length $(\mathrm{cm})$} & & \multicolumn{2}{c}{ Yield $\left(\mathrm{kg} \mathrm{ha}^{-1}\right)$} \\
\cline { 2 - 3 } \cline { 5 - 6 } & DKB 390 & BRS 1010 & & DKB 390 & BRS 1010 \\
\hline January 20 & $15.02 \mathrm{aA}$ & $13.92 \mathrm{aB}$ & & $5,970 \mathrm{bB}$ & $7,578 \mathrm{aA}$ \\
February 7 & $13.81 \mathrm{bA}$ & $12.46 \mathrm{cB}$ & & $6,802 \mathrm{aA}$ & $5,324 \mathrm{cB}$ \\
February 28 & $13.34 \mathrm{cA}$ & $13.20 \mathrm{bA}$ & & $5,296 \mathrm{cB}$ & $5,999 \mathrm{bA}$ \\
March 14 & $13.88 \mathrm{bA}$ & $13.61 \mathrm{bcA}$ & & $5,975 \mathrm{bB}$ & $6,320 \mathrm{Ba}$ \\
\hline
\end{tabular}

\begin{tabular}{llc}
\hline \multirow{2}{*}{ Sowing time } & \multicolumn{3}{c}{ Hundred-grain weight $(\mathrm{g})$} \\
\cline { 2 - 3 } & DKB 390 & BRS 1010 \\
\hline January 20 & $31.20 \mathrm{aB}$ & $32.17 \mathrm{aA}$ \\
February 7 & $31.11 \mathrm{aA}$ & $30.49 \mathrm{bB}$ \\
February 28 & $30.30 \mathrm{bA}$ & $26.86 \mathrm{cB}$ \\
March 14 & $30.12 \mathrm{bB}$ & $31.96 \mathrm{aA}$ \\
\hline
\end{tabular}

Means followed by the same lowercase letters in the column and upper case in the row do not differ statistically from each other by Tukey's test $(p>0.05)$.

The highest grain yield was obtained by the hybrid BRS 1010, in the first sowing time. The lowest yield for the same hybrid occurred in the second sowing time. For the hybrid DKB 390, sowings performed 
at the beginning of February favor the best average performance. It can be observed that grain yield was higher in all periods to the average yield of the country, which is around $5,000 \mathrm{~kg} \mathrm{ha}^{-1}$ (CONAB, 2017). According to Galvão et al. (2014b), the yield potential to be obtained in each sowing time will depend mainly on the amount of solar radiation, the efficiency of interception and conversion of the intercepted radiation into phytomass, and the efficiency of partitioning assimilates to the structure of economic interest.

Thus, the choice of both the hybrid type and sowing time will determine the success or failure of the second season. It is worth noting that in a given region, the cultivar type, cycle, and disease tolerance will play a key role on this process, depending on the sowing time (Perin et al., 2009). In the region of Dourados, late sowings can lead to great risks due to the frequent frosts occurring in the region.

It was observed that the hundred-grain weight followed grain yield similarly in each environment. This result was expected, since the hundred-grain weight is one of the main yield components, as well as ear length, both having a positive correlation with grain yield, as reported by Entringer et al. (2014).

As there was no significance for stem diameter and total chlorophyll in any of the interactions, the isolated interpretation of times, and later of hybrids was performed for these characters (Table 6).

Table 6 - Means for stem diameter and total chlorophyll of two hybrids in four sowing times.

\begin{tabular}{lcc}
\hline Sowing time & Stem diameter $(\mathrm{mm})$ & Total chlorophyll $(\mathrm{a}+\mathrm{b})$ \\
\hline January 20 & $22.51 \mathrm{a}$ & $67.93 \mathrm{a}$ \\
February 7 & $22.71 \mathrm{a}$ & $62.48 \mathrm{~b}$ \\
February 28 & $18.96 \mathrm{~b}$ & $65.43 \mathrm{ab}$ \\
March 14 & $18.71 \mathrm{~b}$ & $64.19 \mathrm{ab}$ \\
\hline Hybrid & - & - \\
\hline DKB 390 & $21.06 \mathrm{a}$ & $67.00 \mathrm{~b}$ \\
BRS 1010 & $20.38 \mathrm{~b}$ & $67.00 \mathrm{a}$ \\
\hline
\end{tabular}

Means followed by the same letters in the column do not differ statistically from each other by Tukey's test $(p>0.05)$.

For stem diameter, the first and second season were the ones that provided the highest values. The stem diameter is an important character, because plants with larger diameters have greater resistance to lodging, thus allowing a better management and lower risk of harvest losses.
Regarding the evaluation of plant populations, it was observed that the linear regression coefficients (b1) were highly significant $(P<0.01)$ for all the characters, except for ear height $(P<0.05)$. The coefficients of quadratic (b2) and cubic (b3) regression were not significant for all the characters evaluated (Table 7).

Table 7 - Summary of the regression variance analysis for seven characters evaluated in four plant populations.

\begin{tabular}{|c|c|c|c|c|c|c|c|}
\hline \multirow{2}{*}{ Causes of variation } & \multicolumn{7}{|c|}{ Mean square } \\
\hline & $\mathrm{EH}$ & SD & ED & EL & HGW & ChlorT & NEP \\
\hline Linear (b1) & $0.02^{*}$ & $23.986^{* *}$ & $54.32^{* *}$ & $30.87^{* *}$ & $183.15^{* *}$ & $473.36^{* *}$ & $1351.40^{* *}$ \\
\hline Quadratic (b2) & $0.00^{\text {ns }}$ & $2.04^{\mathrm{ns}}$ & $0.14^{\mathrm{ns}}$ & $1.22^{\mathrm{ns}}$ & $1.70^{\mathrm{ns}}$ & $2.59^{\text {ns }}$ & $1.83^{\text {ns }}$ \\
\hline Cubic (b3) & $0.00^{\text {ns }}$ & $0.52^{\mathrm{ns}}$ & $2.97^{\mathrm{ns}}$ & $0.26^{\mathrm{ns}}$ & $0.60^{\mathrm{ns}}$ & $83.78^{\text {ns }}$ & $5.01^{\mathrm{ns}}$ \\
\hline Regression Deviation & 0.00 & 0.00 & 0.00 & 0.00 & $0.00^{\text {ns }}$ & 0.00 & $0.00 \mathrm{~ns}$ \\
\hline Error & 0.01 & 1.88 & 1.86 & 0.51 & 2.58 & 19.44 & 5.66 \\
\hline
\end{tabular}

EH: ear height (m); SD: stem diameter (mm); ED: ear diameter $(\mathrm{mm})$; EL: ear length $(\mathrm{cm})$; HGW: hundred-grain weight $(\mathrm{g})$; ChlorT: total chlorophyll $(a+b)$; NEP: number of ear per plot; ${ }^{* *},{ }^{*}$, ns: Significant $(p<0.01)$, significant $(p<0.05)$ and not significant, respectively, by the $\mathrm{F}$ test.

Differently from that shown for plant height, which did not present significance for the source of variation, the ear insertion height increased linearly as a function of population increase (Figure $2 \mathrm{~A}$ ), a result also obtained by Kappes et al. (2011a), demonstrating greater internode elongation through the combined effect of intraspecific competition, especially in large populations. 

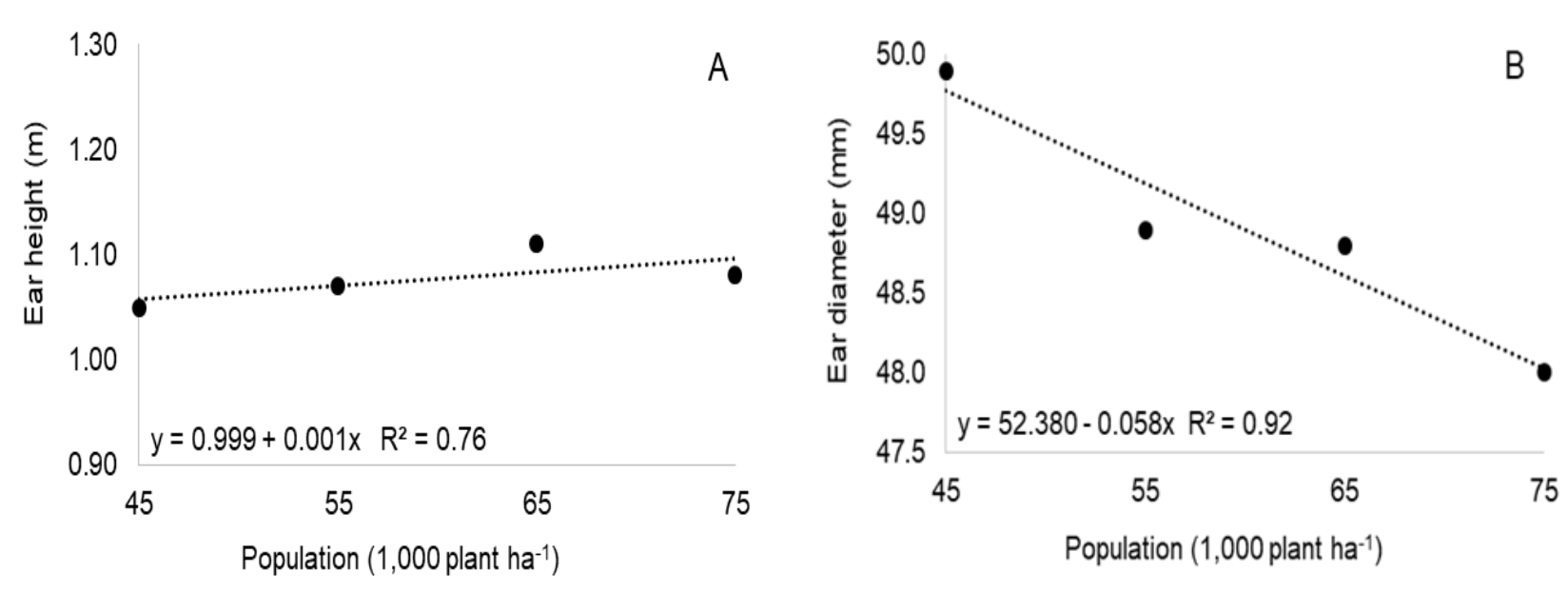

Figure 2 - Ear height $(A)$ and ear diameter $(B)$ of two corn hybrids grown in four plant populations; $F=0.02^{*}(A)$, $F=54.32^{\star \star}(B)$.

For ear diameter, it was observed a reduction as a function of increased plant populations, where for each 1,000 plants added to the population, there is a reduction of $0.0582 \mathrm{~mm}$ in this variable. According to the coefficient of determination, the selected regression model explains $94 \%$ of the variation of this character as a function of plant populations. Similar result were also obtained by Brachtvogel et al. (2009a), where the authors attributed the results obtained to the effect of intraspecific competition on the ear. This is because, to the extent that plant density increases, less environmental resources are available for each plant, directly reflecting the ear size.

The increase from 45,000 to 75,000 plants ha ${ }^{-1}$ caused a linear decrease in stem diameter (Figure 3A), which is in agreement with Dourado Neto et al. (2003a). These authors observed that the larger the population density, the smaller the stem diameter. Taiz \& Zeiger (2010) explain that in large populations, plants allocate their resources for faster growth in order to avoid shading, increasing the possibility of growth above the canopy, but reducing the stem diameter and leaf area.
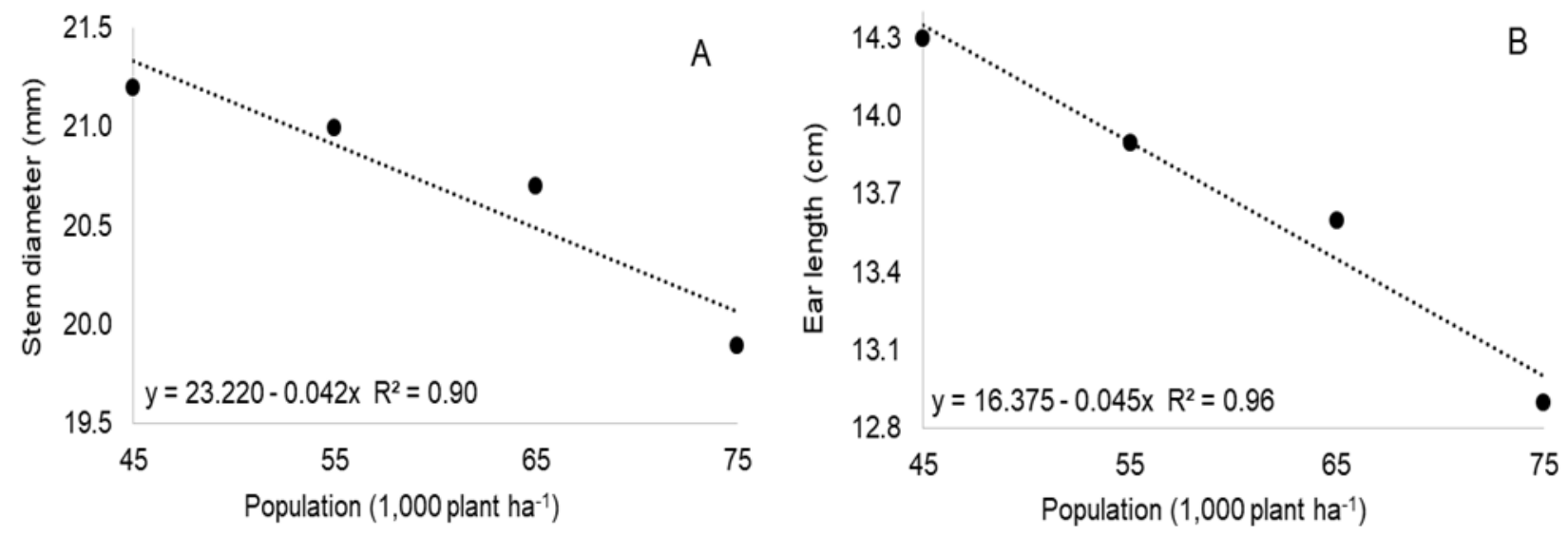

Figure 3 - Stem diameter $(A)$ and ear length $(B)$ of two corn hybrids cultivated in four plant populations; $F=$ $23.98^{* *}(A), F=30.87^{* *}(B)$.

It was observed that the increase in plant population provided a linear decrease in ear length. Therefore, it can be inferred that by promoting greater intraspecific competition among maize plants, there was a decrease in the size of certain structures thereof, such as ears. It should be emphasized that the results obtained in the present work are in agreement with those obtained by Brachtvogel et al. (2009b) and Kappes et al. (2011b), which showed a progressive decrease in ear length as a function of the population increase. Nonetheless, Dourado Neto et al. (2003b) verified that in plant populations between 30,000 and $60,000 \mathrm{ha}^{-1}$, by reducing the spacing from 0.8 to $0.4 \mathrm{~m}$, there was an increase in ear length for all genotypes evaluated. In contrast, for populations above 65,000 plants ha $^{-1}$, the authors did not observe this increase, which is probably due to intraspecific competition for water, nutrients, and light. 
The hundred-grain weight is an important component in maize production, and this character presented similar performance to other yield components when affected by plant population (Figure 4A). However, this result contradicts Borrás et al. (2003), who reported that this character is the production component less affected by variations in management practices.

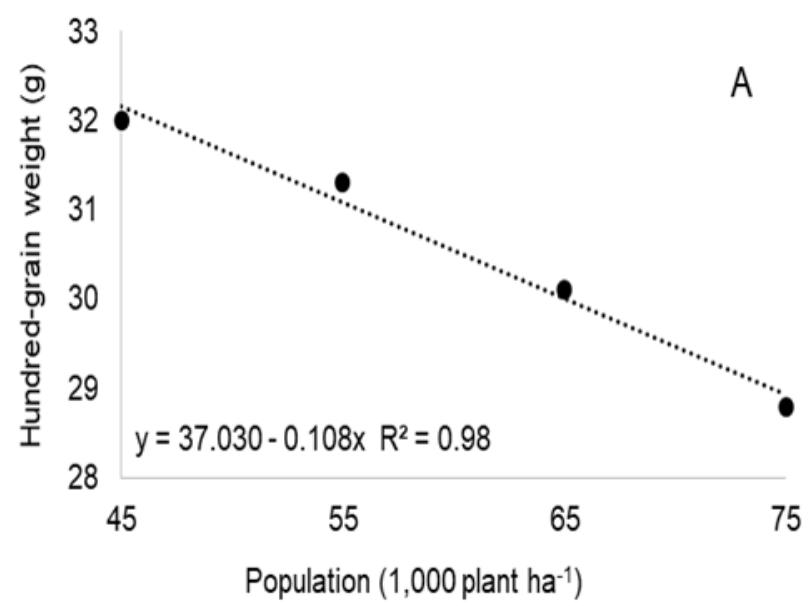

Figure 4 - Hundred-grain weight $(A)$ and total chlorophyll $(a+b)(B)$ of two corn hybrids grown in four plant populations; $F=183.15^{\star *}(A), F=473.36^{\star *}(B)$.

The increase in plant population led to a linear increase in the number of ears. According to the equation, the increase of 1,000 plants resulted in an increase of 0.29 ears (Figure 5 ).

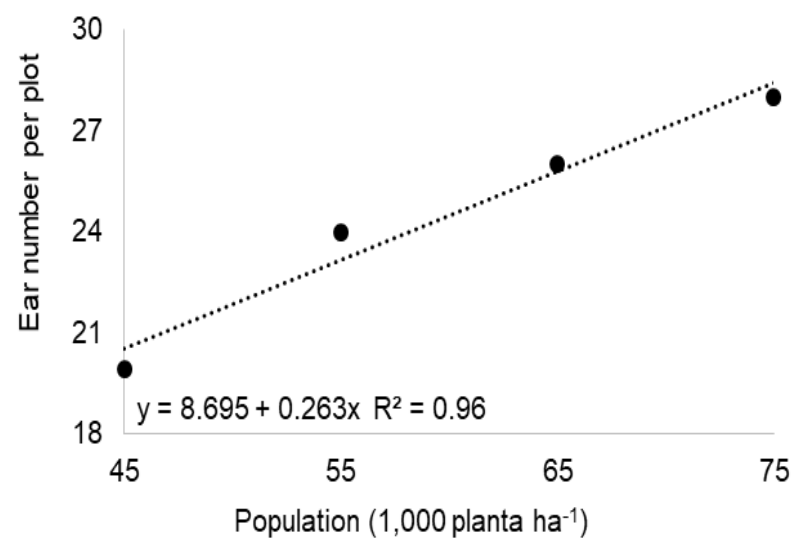

Figure 5 - Ear number per plot of two corn hybrids cultivated in four plant populations; $F=1351.40^{\star *}$.

Kappes et al. (2011c) observed a reduction in the number of ears due to increased plant population, and the authors attributed this result to the fact that in low population densities, competition between plants for water, light, and nutrients is small, thus providing the plants with the resources needed to fill the grains in more than one ear per plant. Nonetheless, the results obtained in the present study differed from those reported by Silva et al. (2008) and Kappes et al. (2011d).
This character showed a linear decrease as the plant population increased, demonstrating that the increase in the population changed the rate and duration of the grain-filling stage. The result obtained agrees with that observed by Strieder et al. (2007), who evaluated two hybrids in the state of Rio Grande do Sul, in different plant populations and four row spacings.

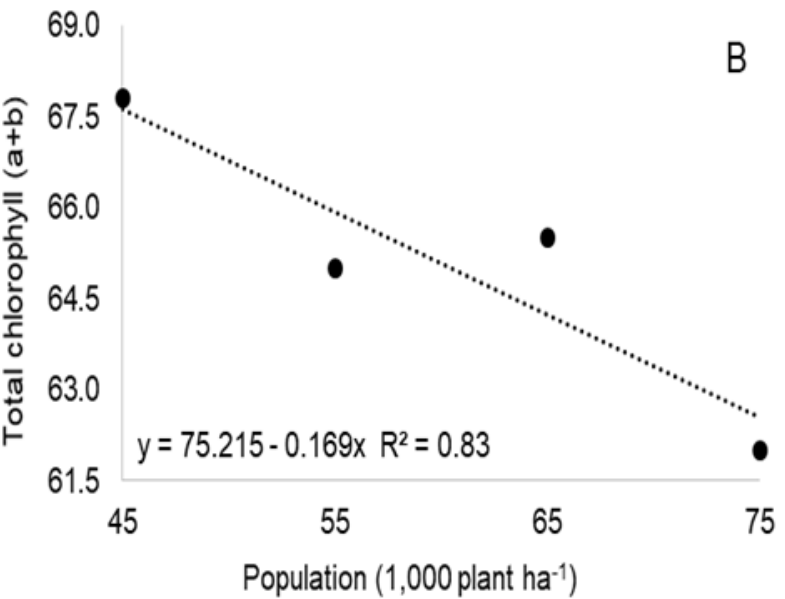

\section{Conclusions}

For grain yield, plant height, and number of rows per ear, the performance of hybrids BRS 1010 and DKB 390 VT PRO2 coincide, regardless of the plant population.

The maize crop developed better in the sowings performed on Jan 20 and Feb 07, and late sowings negatively affect yield.

Among the hybrids studied in the population ranging from 45,000 to 75,000 plants ha-1 ${ }^{-1}$, there was a reduction in the ear diameter and hundred-grain weight, without affecting, however, the grain yield.

\section{References}

Alves VB, Padilha NS, Garcia RA, Ceccon G (2013) Milho safrinha consorciado com Urochloa ruziziensis e produtividade da soja em sucessão. Revista Brasileira de Milho e Sorgo 12(3):280-292. doi: http://dx.doi.org/10.18512/1980-

6477/rbms.v12n3p280-292

Borrás L, Maddonni GA, Otegui ME (2003) Leaf senescence in maize hybrids: plant population, row spacing and kernel set effects. Field Crops Research 82(1):13-26. doi: https://doi.org/10.1016/S03784290(03)00002-9

Brachtvogel EL, Pereira FRS, Cruz SCS, Bicudo SJ (2009) Densidades populacionais de milho em arranjos espaciais convencional e equidistante entre plantas. Ciência Rural 39(8):2334-2339. 
Carvalho RP, Pinho RGV, Davide LMC (2011) Desempenho de cultivares de milho quanto à eficiência de utilização de nitrogênio. Revista Brasileira de Milho e Sorgo 10(2):108-120. doi: http://dx.doi.org/10.18512/1980-6477/rbms.v10n2p108120

Cherubin MR, Fabris C, Weirich SW, Rocha EMT, Basso CJ, Santi AL, Lamego FP (2014) Desempenho agronômico do milho em sucessão a espécies de cobertura do solo sob sistema plantio direto no Sul do Brasil. Global Science and Technology 7(1):76-85.

CONAB - Companhia Nacional de Abastecimento (2017) Acompanhamento da safra brasileira: GrãosSafra 2017/18, 3o levantamento. Disponível em <http://www.conab.gov.br/conteudos.php?a=1253> (Acesso em 20 dez 2017).

Costa RV, Simon J, Silva DD, Cota LV, Almeida REM, Campos LJM (2017) Cultivares de milho afetadas pela época de semeadura na safrinha em Tocantins. Revista Brasileira de Milho e Sorgo 16(3):469-480. doi: http://dx.doi.org/10.18512/1980-6477/rbms.v16n3p469480

Dourado Neto D, Palhares M, Vieira PA, Manfron PA, Medeiros SLP, Romano MR (2003) Efeito da população de plantas e do espaçamento sobre a produtividade de milho. Revista Brasileira de Milho e Sorgo 2(3):63-77. doi: http://dx.doi.org/10.18512/19806477/rbms.v2n3p63-77

Embrapa-CPAO (2014) Guia Clima: Banco de Dados. Disponível em:

http://www.cpao.embrapa.br/clima/?lc=site/banco-

dados/construtor-basico> (Acesso em 20 dez 2017).

Entringer GC, Santos PHAD, Vettorazzi JCF, Cunha KS, Pereira MG (2014) Correlação e análise de trilha para componentes de produção de milho superdoce. Revista Ceres 61(3):356-361. doi: http://dx.doi.org/10.1590/S0034-737X2014000300009

Ferreira MMM (2012) Sintomas de deficiências de macro e micronutrientes de plantas de milho hibrido BRS 1010. Revista Agroambiental 6(1):74-83. doi: http://dx.doi.org/10.18227/1982-8470ragro.v6i1.569

Galvão JCC, Miranda GV, Trogello E, Fritsche-Neto R (2014) Sete décadas de evolução do sistema produtivo da cultura do milho. Revista Ceres 61(1): 819-828.

Kappes C, Andrade JAC, Arf O, Oliveira AC, Arf MV, Ferreira JP (2011) Desempenho de híbridos de milho em diferentes arranjos espaciais de plantas. Bragantia 70(2):334-343. doi: http://dx.doi.org/10.1590/S000687052011000200012
MAPA - Ministério da Agricultura, Pecuária e Abastecimento (2018) Risco Climático, Safra Vigente, Mato Grosso do Sul. Disponível em: $<$ http://www.agricultura.gov.br/assuntos/riscosseguro/risco-agropecuario/portarias/safravigente/mato-grosso-do-sul> (Acesso em 06 fev 2018).

Neto-Neto AL, Silva JF, Santos A, Padilha NS, Makino PA, Ceccon G (2013) Morphophysiology and yield of late season maize intercropped with Urochloa in reduced row spacing. Revista Brasileira de Milho e Sorgo 12(3):227-239. doi: http://dx.doi.org/10.18512/1980-6477/rbms.v12n3p227239

Pereira FCBL, Mendonça VZ, Leal ST, Rossetto JE (2014) Avaliação econômica e do desempenho técnico do milho consorciado com duas espécies forrageiras dos gêneros panicum e brachiaria em sistema de integração lavoura-pecuária. Revista Agrarian 7(23):157165.

Perin A, Guareschi RF, Silva Junior HR, Silva A, Azevedo WR (2009) Produtividade de híbridos de milho na safrinha em Goiás. Agrarian 2(3):19-28.

Resende SG, Pinho RGV, Vasconcelos RD (2003) Influência do espaçamento entre linhas e da densidade de plantio no desempenho de cultivares de milho. Revista Brasileira de Milho e Sorgo 2(3):34-42. doi: 6477/rbms.v2n3p34-42 http://dx.doi.org/10.18512/1980-

Santos HG, Jacomine PKT, Anjos LHC, Oliveira VA, Lumbreras JF, Coelho MR, Almeida JA, Cunha TJF, Oliveira JB (2013) Sistema brasileiro de classificação de solos. Embrapa Solos. 353p.

Santos VA, Silva CA (2012) O clima de Dourados (MS) e a proposição de um roteirometodológico simples para entender a poluição atmosférica de áreas urbanas. Revista Geonorte 3(5):969-982.

Silva AG, Cunha Junior CR, Assis RL, Imolesi AS (2008) Influência da população de plantas e do espaçamento entre linhas nos caracteres agronômicos do hibrido de milho P30K75 em Rio Verde, Goiás. Bioscience Journal 24(2):89-96.

Silva PRF, Piana AT, Maass LB, Serpa MS, Sangoi L, Vieira VM, Endrigo PC, Jandrey DB (2010) Adequação da densidade de plantas à época de semeadura em milho irrigado. Revista de Ciências Agroveterinárias $9(1): 48-57$.

Strieder ML, Silva PRF, Argenta G, Rambo L, Sangoi L, Silva AA, Endrigo PC (2007) A resposta do milho irrigado ao espaçamento entrelinhas depende do hibrido e da densidade de plantas. Ciência Rural 37(3):634-642. doi: http://dx.doi.org/10.1590/S010384782007000300006 
Taiz L, Zeiger E (2010) Plant Physiology. Sinauer Associates. 782p.
Van Roekel RJ, Coulter JÁ (2012) Agronomic responses of corn hybrids to row width and plant density. Agronomy Journal 104(3):612-620. doi: 10.2134/agronj2011.0380 